\title{
Ecotoxicological evaluation of sediments applied to environmental forensic investigation
}

\author{
R. H. Alves ${ }^{a *}$ and A. C. Rietzler ${ }^{a}$ \\ áLaboratório de Ecotoxicologia, Departamento de Biologia Geral, Instituto de Ciência Biológicas, Universidade Federal de \\ Minas Gerais - UFMG, Av. Antonio Carlos, 6627, CEP 31270-901, Belo Horizonte, MG, Brazil \\ *e-mail: alvesrodrigoh@yahoo.com.br
}

Received: February 19, 2014 - Accepted: June 16, 2014 - Distributed: November 30, 2015

(With 5 figures)

\begin{abstract}
The present study aimed to evaluate the potential for using toxicity assays with sediment samples for the detection of water pollution caused by the discharge of tannery effluents into water bodies and its application to environmental forensic investigation. The study included ecotoxicological evaluation of sediments, survey of benthic organisms in the field, as well as chromium, cadmium and lead dosage which provided data for a sediment quality triad evaluation. The sediment samples showed acute and chronic toxicity to the bioindicators, low biodiversity of benthic macrofauna and high chromium concentration, reaching up to $4365 \mathrm{mg} \cdot \mathrm{Kg}^{-1}$. A close relationship was observed between the separate results of ecotoxicological sediment evaluation and the sediment quality triad. The sediment ecotoxicological assessment proved to be applicable to tracking sources of contamination related to tanneries and similar activities in environmental forensics.
\end{abstract}

Keywords: environmental forensics, ecotoxicological evaluation of sediments, sediment quality triad, tannery effluents, toxicity of chromium.

\section{Avaliação ecotoxicológica de sedimentos aplicada à perícia criminal ambiental}

\section{Resumo}

O objetivo do presente estudo foi avaliar o potencial de aplicação de ensaios de toxicidade com amostras de sedimento para constatação de poluição aquática causada por lançamentos de efluentes de curtumes em cursos d'água e seu emprego na perícia criminal ambiental. O estudo incluiu avaliação ecotoxicológica de sedimentos, avaliação da fauna bentônica local e dosagem de cromo, cádmio e chumbo que forneceram dados para avaliação da tríade de qualidade dos sedimentos. As amostras de sedimentos mostraram efeito de toxicidade aguda e crônica aos bioindicadores, baixa biodiversidade da macrofauna bentônica e altas concentrações de cromo que chegaram a $4365 \mathrm{mg} \cdot \mathrm{Kg}^{-1}$. Houve uma estreita relação entre os resultados isolados da avaliação ecotoxicológica e a tríade de qualidade de sedimentos. A avaliação ecotoxicológica demonstrou ser aplicável na identificação de fontes de contaminação relacionadas a curtumes e atividades similares em perícias ambientais.

Palavras-chave: perícia ambiental, avaliação ecotoxicológica de sedimentos, tríade de qualidade de sedimentos, efluentes de curtumes, toxicidade do cromo.

\section{Introduction}

Industrial pollution is among the main sources of environmental degradation, especially with regard to its impact on water bodies (Satterthwaite, 1997; Callisto et al., 2012). Brazilian legislation concerning environmental pollution was essentially administrative, including licensing, environmental education and control. However, faced with the reality that only administrative and civil steps can no longer control pollution issues, the current trend is to treat such acts of pollution as criminal, leading to a more aggressive way of control.
In Brazil, since the "Environmental Crime Law" (Brasil, 1998) was established, forensic sections have to examine the impact of environmental crime, as part of the process of evidence acquisition for investigation of environmentally harmful activities. However, the newness of this law, together with the scarcity of scientific literature on the subject, especially applicable to tropical conditions, have been obstacles for the development of this area in Brazil (Barbieri, 2003). Adequate methodologies are required for 
evaluating the different crimes described therein, such as pollution crime, which is the focus of the current study.

Water pollution and extinction of aquatic fauna represent a significant intersectoral policy matter affecting both environmental and public health sectors (Khan and Ghouri, 2011; Callisto et al., 2012). Given the importance of maintaining the quality of water resources, it becomes imperative to propose and test methodologies for the generation of pollution crime evidence data to environmental forensics.

Among the applicable areas for environmental quality evaluation is ecotoxicology, seen as a promising area due to its practicality, relatively low cost of its methods and good results shown in recent studies (Twardowska, 2004; Laitano and Matias, 2006). In such studies live organisms are used as environmental sensors being frequently the focus of conservation issues (or approaches), in compliance with a multitude of legal stipulations, such as those of the Brazilian Environmental Crime Law.

In relation to environmental compartments of a watercourse, sediment is a major repository for many of the most persistent chemicals introduced into surface waters and, if contaminated, may be directly toxic to aquatic life (Ingersoll, 1995). Moreover, sediments are known to reduce the availability of the tested chemicals, acting both as a source and a sink for contaminants (Adams, 1995). This has led to a need for extensive toxicity testing of samples of this segment. Thus, the evaluation of the quality of the sediment is necessary because many contaminants are found only as traces in the water column and can accumulate in the sediment (Chapman, 1989).

Organisms commonly used for assays with sediments are Chironomus sp., Hyalella azteca, and Lumbricus variegatus. Since benthic macroinvertebrates combines characteristics of the water and sediment, they are potential indicators of environmental quality of water resources (Chiba et al., 2011). Although not benthic, cladocerans are often in contact with the sediment surface, being exposed to contaminants released from the sediment (Jardim et al., 2008). According to these authors, the use of two test-organism species made it possible to obtain a better assessment of the condition of both water and sediment samples. In terms of relevant legislation, the only legal document that refers to the contamination of sediments in Brazil is CONAMA Resolution 344/04 (Brasil, 2004), with mandatory ecotoxicological evaluation of activities involving dredged material.

In this context, this study aimed to evaluate the potential for using toxicity assays with sediment samples for the detection of water pollution caused by the discharge of tannery effluents into water bodies and its application to environmental forensic investigation. The focus was the toxicity caused to organisms exposed to sediment samples collected in streams where tannery effluents are discharged. The potential of pollution inherent in this type of industrial activity justifies the proposed methods for effective examination of environmental pollution crime cases. The tanning industry is considered one of the most polluting industries (Jordão et al., 1999). Tannery wastewaters have high contents of organic and inorganic compounds, including toxic substances such as sulfides and chromium salts (Durai and Rajasimman, 2011).

The processes and methods investigated in this study are expected to expand the range of tools available for environmental crime experts when investigating or monitoring the existence of environmental violations of this nature. This study emphasizes the importance of developing adequate standardized protocols in environmental forensics, using a biological or integrated approach. Thus, tools to track sources of contamination were tested, focusing on the assessment of harmful effects of tannery wastewaters on aquatic fauna bioindicators.

\section{Material and Methods}

\subsection{Study area}

The study area included two water bodies, a main stream and its tributary, both receiving effluents from tanneries in an extensively disturbed urban area of a south-central municipality of Minas Gerais State, Brazil.

Sediment samples for preliminary assays were collected in September 2007 (dry season), in two sites suspected of contamination (PA and $\mathrm{PB}$ ), and in a reference site (control - CC). In March (rainy season), and in August (dry season) of 2008, two other suspected sites of contamination (PC and PD) were added to those previously defined for the preliminary assays.

As shown in Figure 1, CC and PA samplings sites were located in the tributary stream, while PB, PC and PD were in the main stream. PA, PB and PC corresponded to sites receiving discharge of tannery effluents. $\mathrm{CC}$ was located upstream of the tannery effluent discharges and PD downstream of all the sampling sites

\subsection{Sediment toxicity assays}

Acute and chronic toxicity assays using Chironomus xanthus Rempel and Ceriodaphnia silvestrii Daday were performed according to USEPA (1994) and ABNT (2005), respectively. For C. xanthus, five replicate samples of sediment were considered with addition of a third instar larvae to each one. The endpoint for the acute effect was mortality of individuals after 96 hours. For C. silvestrii, ten replicate samples of sediment were tested with one neonate in each one. The chronic endpoint was reproduction in a period of 8 days.

Before the assays were performed, sensitivity tests were carried out. These tests showed that organisms from laboratory cultures were in good conditions for use in the toxicity bioassays, since sensitivity were between 1.14-1.91 mg. $\mathrm{L}^{-1}$ for $C$. silvestrii, using $\mathrm{NaCl}$ as reference substance, and between 4.75-5.42 mg. $\mathrm{L}^{-1}$ for C. xanthus, using $\mathrm{KCl}$.

The results of the toxicity assays were statistically analyzed based on USEPA (2002a, b). 


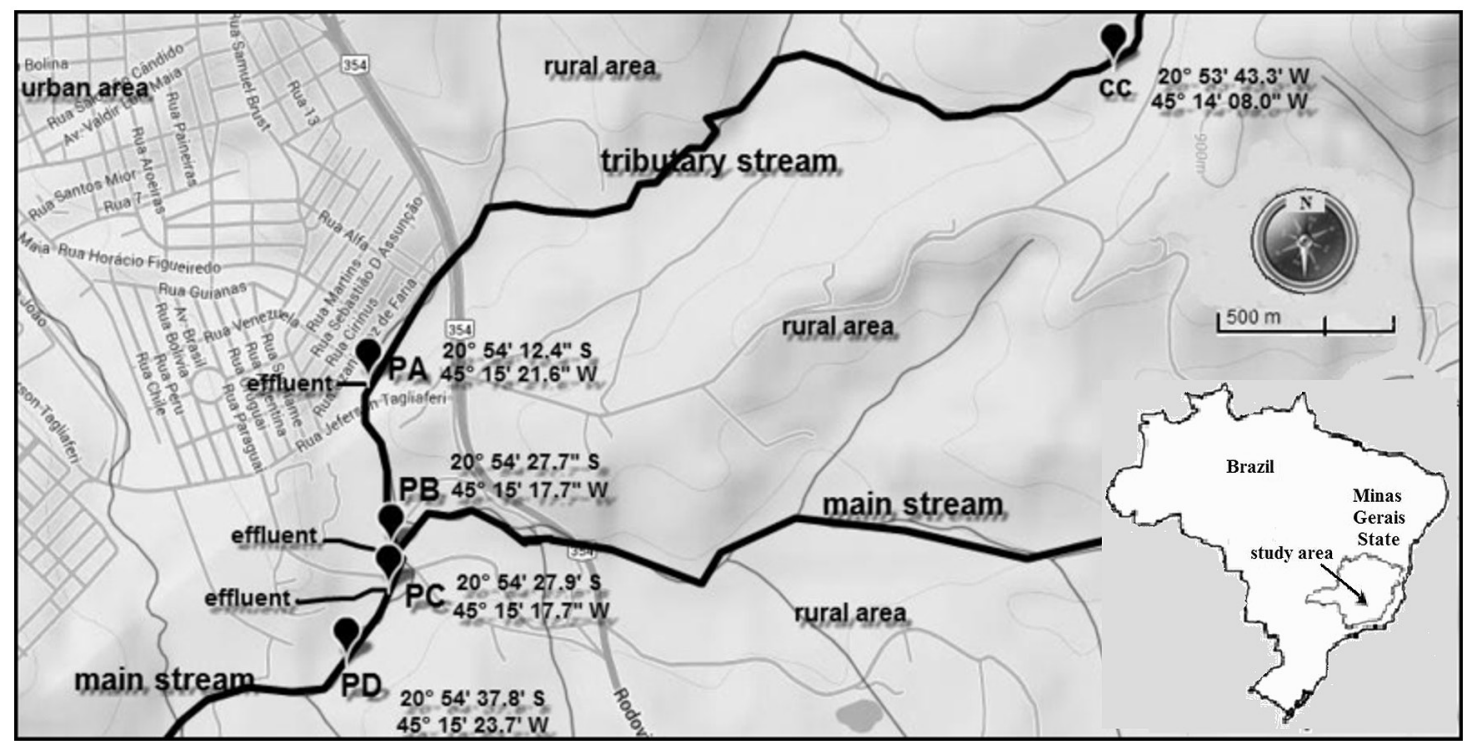

Figure 1. Sampling sites located in the central-southern region of Minas Gerais State, Brazil. Adapted from UFLA (2008).

\subsection{Evaluation of benthic macrofauna}

Sediment samples for benthic macrofauna evaluation were collected at the same sites used for the toxicity assays in August 2008. Three samples along two meters transect were collected with a benthic net. Samples were transferred to plastic bags and preserved with $40 \%$ formaldehyde shortly after collection.

Samples were screened, and the organisms were classified into large groups: Chironomidae, Polycentropodidae (Tricoptera), Oligochaeta, Gastropoda, Tipulidae, Psychodidae and Syrphidae according to Herricks and Cairns Junior (1982). Numerical density (ind. $\mathrm{m}^{2}$ ), percentage of deformity of chironomid menta (Kuhlmann et al., 2000), and Shannon Diversity and Pielou Evenness Indexes were calculated.

\subsection{Chemical analysis}

During the dry season of 2008, sediment samples were collected from the streams sites (CC, PA, PB, PC and PD) and from two tannery effluents (EPB and EPC), discharged into the main stream at $\mathrm{PB}$ and $\mathrm{PC}$, respectively. Samples were preserved and analyzed at the Centre for Development of Nuclear Technology, Belo Horizonte, Minas Gerais, Brazil. The preserved samples were dried, homogenized and analyzed by an EDX-720 Energy-dispersive X-ray spectrometer - Shimadzu, utilizing a rhodium tube with lithium-silicon detection. Concentrations of $\mathrm{Cr}, \mathrm{Cd}$ and $\mathrm{Pb}$ concentrations, metals commonly associated with tannery wastewaters, were measured.

\subsection{Sediment quality triad}

The Sediment Quality Triad Method (Chapman, 1990) was applied to assess sediment quality in the main and tributary streams, based on the results of three studies conducted in the 2008 dry season. It included acute and chronic toxicity assays, assessment of the benthic macrofauna (numerical density, Shannon Diversity Index, Pielou Evenness Index and deformity of the mentum of Chironomidae sp.) and chemical analysis (chromium concentration in the sediment samples).

The results obtained in these studies were converted into ratio-to-reference values (RTR), generating dimensionless numbers. The average value of each sampling point parameter was divided by the mean value obtained for the respective control point parameter. The numbers were generated in sequence reflecting the three indices supporting the integrated study of the area, the Toxicity Index, the Community Index and the Chemical Index. These indices were plotted on a 3-axis graph and the area of the triangles with vertices on the axes was calculated. The larger the area of such an environment-to-control ratio triangle, the more polluted it is.

\section{Results}

\subsection{Sediment toxicity assays}

As shown in Table 1, a statistically significant difference $(p \leq 0.05)$ was found between the control site and PA and PB in the 2007 dry season. In 2008, there was a significant difference between the control site and PB, PC and PD in the rainy season and between the control site and $\mathrm{PB}$ and $\mathrm{PC}$ in the dry season. The most toxic effects were found for sites exposed to tannery effluent discharge (PA, PB and PC), extending downstream (PD).

The results of the chronic toxicity tests, not including sampling sites where acute effects were detected, are shown in Table 2. Significant differences $(p \leq 0.05)$ were found between the number of neonates produced by the control and $\mathrm{PB}$ in the rainy season of 2008, and between the control point and PC and PD in the dry season. Furthermore, toxicity 
Table 1. Percentage of mortality of Chironomus xanthus in sediment acute toxicity assays.

\begin{tabular}{cccc}
\hline $\begin{array}{c}\text { Year } \\
\text { (season) }\end{array}$ & Samples & Mortality (\%) & $\begin{array}{c}\text { Acute Toxicity } \\
\text { (T Test; Fisher Test*) }\end{array}$ \\
\hline $\mathbf{2 0 0 7}$ & CC & $\mathbf{0}$ & Control \\
$(\mathbf{d r y})$ & PA & 100 & Yes \\
& PB & 80 & Yes \\
\hline & CC & 0 & Control \\
$\mathbf{2 0 0 8}$ & PA & 20 & No \\
$($ rainy) & PB & 100 & Yes* \\
& PC & 100 & Yes* \\
& PD & 80 & Yes \\
\hline & CC & 0 & Control \\
$\mathbf{2 0 0 8}$ & PA & 100 & Yes* \\
$($ dry) & PB & 80 & Yes \\
& PC & 60 & No \\
& PD & 60 & No \\
\hline
\end{tabular}

*Fisher Test was used when the data showed null variance.

Table 2. Parental survivorship and total number of neonates of Ceriodaphnia silvestrii in sediment chronic toxicity assays.

\begin{tabular}{ccccc}
\hline Year (season) & Samples & $\begin{array}{c}\text { Toxic effect in parental } \\
\text { survivorship }\end{array}$ & Neonates production & $\begin{array}{c}\text { Chronic Toxicity } \\
\text { (Wilcoxon Rank-Sum) }\end{array}$ \\
\hline \multirow{2}{*}{2008 (rainy) } & CC & Control & 157 & Control \\
& PA & No & 65 & Yes \\
\hline \multirow{2}{*}{2008 (dry) } & CC & Control & 249 & Control \\
& PC & Yes & 11 & Yes \\
& PD & Yes & 0 & Yes \\
\hline
\end{tabular}

effects on parental survivorship were found in PC and PD samples in the dry season of 2008. Thus, all sampling sites where tannery effluents were released showed either acute or chronic toxic effects, even in the rainy season.

\subsection{Evaluation of benthic macrofauna}

All sites evaluated showed low density and diversity of organisms, even the control (see Figure 2). Opposite to this, mentum deformities of the chironomids were observed in $60 \%$ of the organisms from PB (see Figure 3 ). Deformity frequencies of below 3\% in non-polluted environments have been found (Diggins and Stewart, 1993; Hudson and Ciborowski, 1996a).

\subsection{Chemical analysis}

Chromium concentration in dry sediment samples (mg. $\mathrm{Kg}^{-1}$ ) with its corresponding standard deviations (SD) is shown in Figure 4. Cadmium and lead concentrations were below the limit of detection of the adopted method $(0.001 \%)$.

Chromium was not detected in the reference site (CC), with a concentration was below the detection limit ( $7 \mathrm{mg} \cdot \mathrm{Kg}^{-1}$ ) as well as at PD. On the other hand, in the other sites located downstream of the discharge of tannery effluents, this metal was detected. An increasing trend was found from PB to PC. The latter showed the highest concentration (2169 mg. $\mathrm{Kg}^{-1}$ ). Chemical analyses of dry
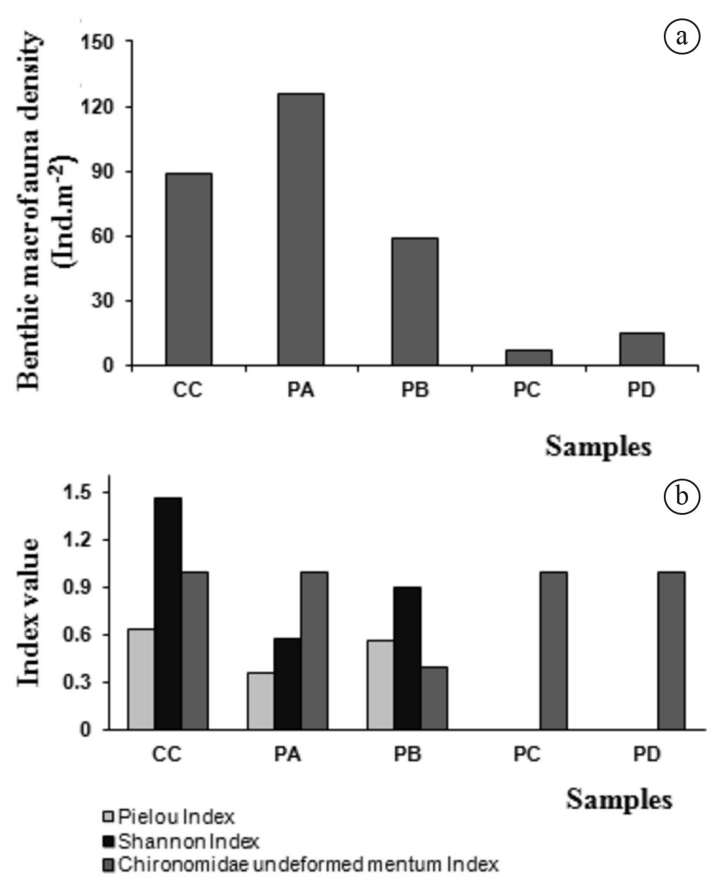

Figure 2. (a) Benthic macrofauna density (ind. $\mathrm{m}^{-2}$ ). (b) Shannon index, Pielou Index and Chironomidae undeformed mentum Index. 

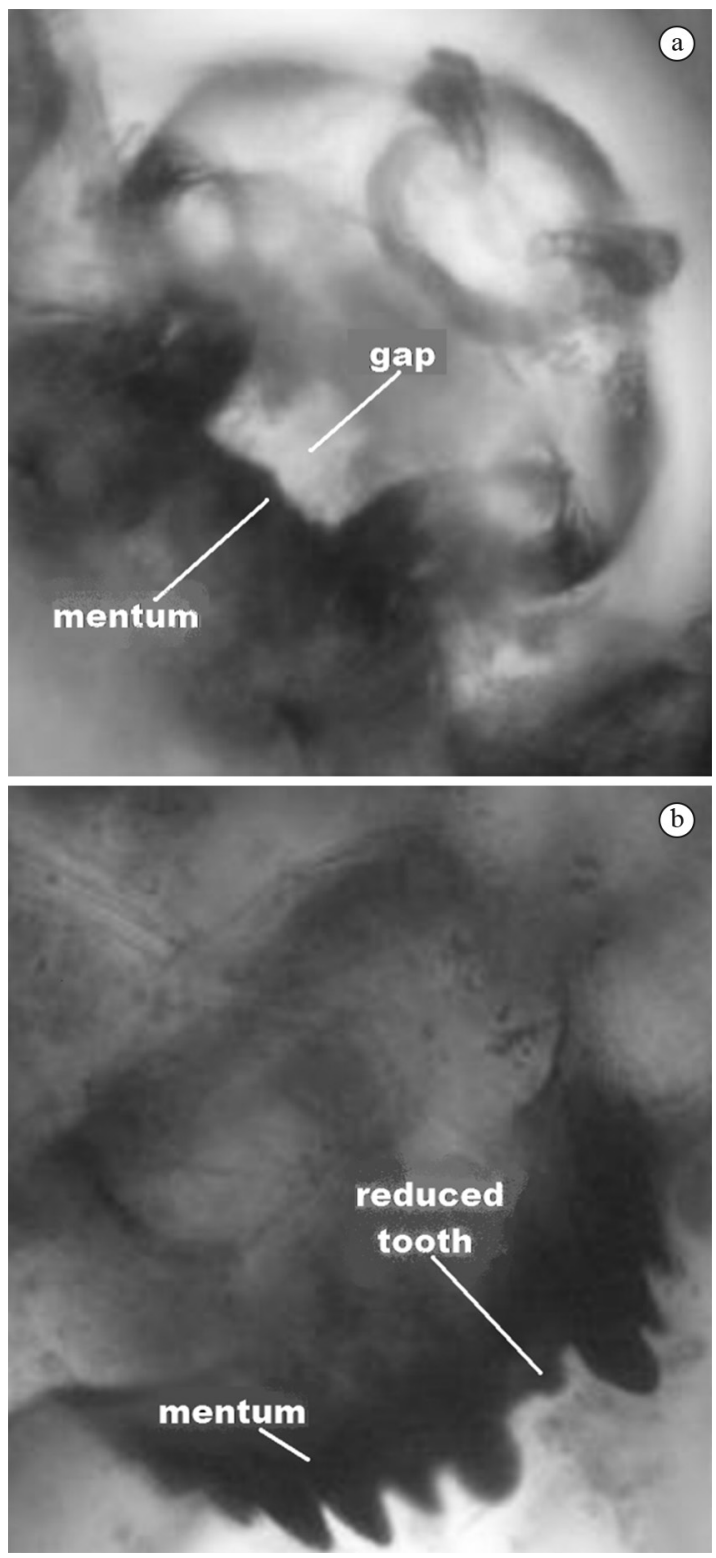

Figure 3. Deformed mentum of chironomids. (a) gap in mentum. (b) reduced and asymmetric tooth. [Photos: Ivan Miller].

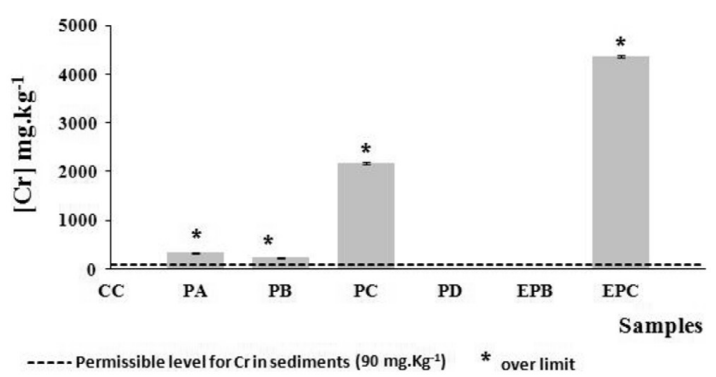

Figure 4. Chromium concentrations in sediment samples, expressed in $\mathrm{mg} \cdot \mathrm{Kg}^{-1}$, with corresponding standard deviation.

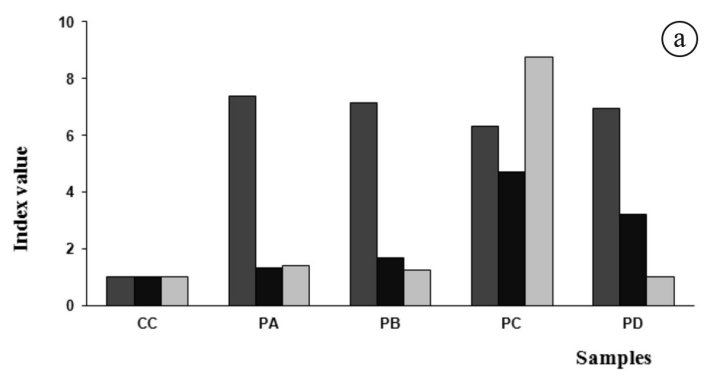

- Toxicity Index (TI) $₫$ Community Index (CI) $\square$ Chemical Index (QI)

(b)

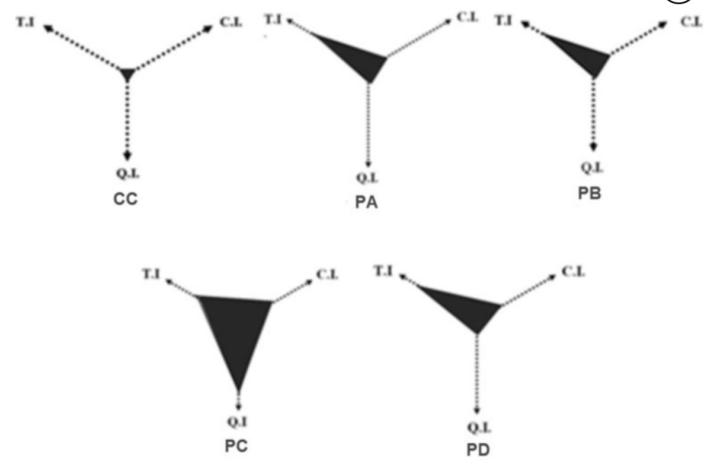

Figure 5. (a) Toxicity Index, Community Index and Chemical Index of the sampling sites. (b) Triangle areas for the sampling sites obtained by these indexes.

sediment samples of eflluents showed a high concentration of chromium only in the EPC effluents (4365 mg. $\mathrm{Kg}^{-1}$ ).

\subsection{Sediment quality triad}

High toxicity levels were found for all sampling sites compared to the control site (see Figure 5a). According to the Community Index, PC presented the worst results, followed by PD. The Chemical Index was higher in PC, followed by PA and PB but not significant in PD.

As shown in Figure 5b, the area of the triangle corresponding to the control site was equal to 0.86 . The areas of the triangle corresponding to PA, PB, PC and PD were 7.24, 7.63, 37.55 and 11.81, respectively. These values were $7.47,8.87,43.66$ and 13.73 times the area of the control site, indicating differences in environmental quality. For sites PA, PB and PD, the toxicity index was the main factor increasing area, while for PC, the Chemical Index was the main factor.

\section{Discussion}

The ecotoxicological evaluation of sediment from the main and tributary streams provided enlightening results concerning the impact of pollution on these environments. The sediment samples from PA to PD, demonstrated acute toxicity for C. xanthus and chronic toxicity for C. silvestrii, at least in one of the three sampling periods. However, all sediment samples showed chronic toxicity in the dry season of 2008. These results characterized toxic effects on sites where tannery effluent is discharged (PA, PB and 
PC). The results for PD, located downstream of all other sample sites, showed that the extension of the pollution impact was extended beyond the points of effluent discharge.

The isolated results of the benthic macrofauna analyses could not confirm the environmental impact of the tanning discharges. This method did not provide any direct correlation with the ecotoxicological assessment of sediments. Even the control itself, located upstream of the effluent discharges, showed low values for organism densities and ecological indices. This may be due to the fact that the study area is in the boundary zone between rural and urban areas, resulting in an adverse environment for macroinvertebrate communities.

Legal standards for chromium in sediments vary between countries. The limit is $250 \mathrm{mg} \cdot \mathrm{Kg}^{-1}$ in the Netherlands, $111 \mathrm{mg} \cdot \mathrm{Kg}^{-1}$ in Canada and $100 \mathrm{mg} \cdot \mathrm{Kg}^{-1}$ in Germany (Reuther, 1999). In Brazil, according to the CONAMA Resolution 344/04 (Brasil, 2004), 37.3 mg. Kg ${ }^{-1}$ chromium is the threshold below which a low probability of impact on biota is anticipated and $90 \mathrm{mg} \cdot \mathrm{Kg}^{-1}$ is the threshold above which an impact on the biota can be expected. PA, PB and PC did not comply with the stipulated quality criteria. In addition, a high concentration of chromium was found in the EPC effluent (4365 mg. $\mathrm{Kg}^{-1}$ ).

Some studies have shown harmful effects of tannery activities to the biota. Few studies related to these activities have been carried out in Minas Gerais. Among these, Jordão et al. (1997) compared chromium concentrations of fluvial sediments with those of non-industrialized areas in the same regions, showing metal inputs from several tanneries. These authors showed chromium concentrations close to the high values found in this study $\left(2878 \mathrm{mg} \cdot \mathrm{Kg}^{-1}\right)$. They showed either that there was an exchange of chromium between biotic and abiotic compartments in the ecosystem. Other study showed mutagenic effects of interstitial water and organic extracts of sediment from rivers affected by tannery effluents to Salmonella sp. (Tagliari et al., 2006). In this context, the high concentration of chromium found in the sediment of the EPC effluent may explain the high levels of toxicity and low biodiversity of benthic macroinvertebrates found at PC.

The success of application of these methods depends on the characteristics of the water body analyzed. When samples collected immediately downstream of the suspected effluent discharge and in the final effluent itself are toxic to bioindicators, opposite to that samples collected upstream them, the source of contamination is proven. On the other hand, if samples collected upstream of the effluent discharge were already toxic, it would be necessary to establish if this effluent enhanced the previous toxicity.

Chemical analyses can be very helpful in both cases described before, identifying and quantifying the contaminant. Although x-ray fluorescence is considered a screening method, chemical analysis could significantly benefit this study. It was shown high concentrations of chromium at the sites where the effluents from tanneries were discharged and in the effluent itself. It enabled the identification of the agent(s) responsible for toxicity in the samples, and the correlation of this agent with its source, as required in environmental forensic investigations. Thus, the combination of chemical analysis with ecotoxicological assays represented a potential tool to track sources of contamination.

On the other hand, the isolated quantification of contaminants does not provide much information about the potential adverse effects on aquatic biota (Ingersoll, 1995). It is indispensable to demonstrate the toxic effects of the environmental contaminant to the local biota, as the basis of evidence for the implementation of legal proceedings. In this context, ecotoxicological evaluation involves the integration of chemical, physical and biological methods (La Point, 1995). Therefore, the ecotoxicological approach has great value, since it clearly assess the potential damage to the biota and the ecosystem as a whole (Zagatto and Bertoletti, 2006).

It is necessary to emphasize that other substances, not considered in the present study, may also have influenced the toxicity detected. Tannery wastewater contains large quantities of other toxic substances besides chromium such as sulfides and ammonium, to which have been attributed toxic effects to biota (Durai and Rajasimman, 2011). Furthermore, the chemical form of chromium, also not analyzed in this study, can influence the toxicity of the samples. Free hydrated $\mathrm{Cr}$ ions and stable complexes of these ions have different toxicity effects. Chromium has been described to be fully speciated in the receiving waters, predominating its associations with macromolecular particles in complexed or colloidal forms (Walsh and O'Halloran, 1996). Only a small portion of free metal ions stay dissolved in the water. Due to adsorption, hydrolysis and co-precipitation, a large quantity of these ions get deposited in the sediment, which may act as a sink and a source of pollution (Beg and Ali, 2008).

It is known that chromium may be present naturally in low concentrations in aquatic ecosystems, without compromising the environment (Jordão et al., 1999). This metal is the major constituent of tannery effluent (Sreenivasan and Krishna Moorthy, 2011), but it can be also provided by other human activities. Esediments in rives in Brazil (Jordão et al., 1997). Thus, smaller contributions to the contamination verified in this study could have come from not identified clandestine tanneries or even from other sources of contamination.

The three indices from the integrated assessment provided results that complemented each other. Although chromium concentration at PD was below the limit of detection of the utilized method, samples taken at that point were toxic to organisms. The high PD Community Index corroborated these results. In the triad approach, the integration of parameters enabled better identification of the environmental quality of the studied sites, in comparison with the reference site. Sampling sites receiving tannery effluent discharges were significantly more impacted than the reference site. Particularly in PC, the impact was estimated to be 43.66 times greater than the reference site. A close correlation was observed between the results of the 
sediment quality triad evaluation and the isolated results of ecotoxicological sediment evaluation in the water bodies. It indicated that ecotoxicological sediment assessment may safely be used to provide proof of environmental impact. It showed high potential to produce robust evidences of the impact of similar activities in cases of suspected contamination of water bodies.

Based on the recent criminalization of actions harmful to the environment in Brazil and in other regions of the world, it has become imperative to establish methodologies capable of generating evidential data of this type of crime, such as pollution. The relevance of this study lies in the importance of maintaining the quality of water resources and biodiversity worldwide. The present study is especially applicable to developing countries, which often cannot rely on precision analytical instruments, which, in addition to their high cost, do not directly demonstrate the impact of pollution on biodiversity.

Other environmental forensic methods have been applied for Cr source evaluation in aquatic compartments. In general, they use a metal chemical analysis approach (Fang and Yang, 2010). Some studies have included biological parameters, emphasizing the monitoring of contaminants in organisms tissues (Rejomon et al., 2008). A new approach is the geochemical condition of surface sediments, by the elemental interactions, using statistical methods and factor analysis (Balachandran et al., 2006). Although these advances, further studies evaluating the effect of trace elements on organisms are needed, including other ecotoxicological methods and other potential bioindicators.

It was concluded that sediment samples from the study area demonstrated acute toxicity for $C$. xanthus and chronic toxicity for $C$. silvestrii. This study appointed that the ecotoxicological assays with sediment samples can be used for rapid, practical and accurate tracking and monitoring of water bodies pollution by tannery effluents. They provide evidence in environmental forensic investigations, tracking sources of contamination, mainly when toxicity assays are carried out with sediment samples collected upstream and downstream of the suspected effluent discharge and with the effluent itself. The authors suggest the evaluation of these methods with other anthropogenic sources of water contamination applied to environmental forensic investigation.

\section{Acknowledgements}

The authors would like to thank Zilmar Lula from Centre for Development of Nuclear Technology (CDTN), Belo Horizonte, Brazil, for helping with chemical analyses, and Dr. Kennedy Roche for his improvements of an earlier draft.

\section{References}

ADAMS, W.J., 1995. Aquatic toxicololy testing methods. In: D.J. HOFFMAN, B.A. RATTNER and G.A.J. BUTON, orgs. Handbook of ecotoxicology. Boca Raton: Lewis Publishers, pp. 25-34.
ASSOCIAÇÃO BRASILEIRA DE NORMAS TÉCNICAS ABNT, 2005. NBR 13373: ecotoxicologia aquática: toxicidade crônica: método de ensaio com Ceriodaphnia spp. (Crustácea, Cladocera). Rio de Janeiro.

BALACHANDRAN, K.K., LALURAJ, C.M., MARTIN, G.D., SRINIVAS, K. and VENUGOPAL, P., 2006. Environmental analysis of heavy metal deposition in a flow-restricted tropical estuary and its adjacent shelf. Environmental Forensics, vol. 7, no. 4, pp. 345-351. http://dx.doi.org/10.1080/15275920600996339.

BARBIERI, C.B., 2003. Subsídios para desenvolvimento de metodologia de perícia criminal ambiental: estudo de caso de poluição ambiental ocasionada por aterro de residuos industriais perigosos em Arroio do Meio, RS. Porto Alegre: Instituto de Biociências, Universidade Federal do Rio Grande do Sul, pp. 345-351. Dissertação de Mestrado.

BEG, K.R. and ALI, S., 2008. Chemical contaminants and toxicity of Ganga river sediment from up and down stream area at Kanpur. American Journal of Environmental Sciences, vol. 4, no. 4, pp. 362-366. http://dx.doi.org/10.3844/ajessp.2008.362.366.

BRASIL, 1998 [viewed 27 March 2012]. Lei $n^{\circ} 9.605$, de 12 de fevereiro de 1998. Dispõe sobre as sanções penais e administrativas derivadas de condutas e atividades lesivas ao meio ambiente, $e$ dá outras providências. Diário Oficial da República Federativa do Brasil [online], Brasilia, 13 fev. Available from: http://www2. camara.leg.br/legin/fed/lei/1998/lei-9605-12-fevereiro-1998365397-normaatualizada-pl.pdf.

BRASIL. Conselho Nacional do Meio Ambiente - CONAMA, 2004 [viewed 27 March 2012]. Resolução CONAMA n ${ }^{\circ} 344$, de 25 de março de 2004. Estabelece as diretrizes gerais e os procedimentos mínimos para a avaliação do material a ser dragado em águas jurisdicionais brasileiras, e dá outras providências. Diário Oficial da República Federativa do Brasil [online], Brasilia, 7 maio. Seção 1, pp. 56-57. Available from: http://www.mma.gov.br/ port/conama/legislacao/CONAMA_RES_CONS_2004_344.pdf.

CAllisto, M., CASTRO, D., MORAIS, L., HUGHES, F.M., KIMURA, A., ALVES, R., FREITAS, V., GAGLIARDI, L., GUIMARÃES, L.C., GUTIERREZ, M.A., LIGEIRO, R., MIRANDA, R.F., RESENDE, F. and SALES, S.C.M., 2012. Gestão eficiente de bacias hidrográficas no Brasil: dificuldades e perspectivas de soluções. Natureza \& Conservação, vol. 10, no. 1, pp. 1-4. http://dx.doi.org/10.4322/natcon.2012.016.

CHAPMAN, P.U., 1989. Concepts and strategies for biological monitoring. London: GEMS/University of London. $45 \mathrm{p}$.

CHAPMAN, P.M., 1990. The sediment quality triad approach to determining pollution-induced degradation. The Science of the Total Environment, vol. 97-98, pp. 815-825. http://dx.doi. org/10.1016/0048-9697(90)90277-2.

CHIBA, W.A.C., PASSERINI, M.D. and TUNDISI, J.G., 2011. Metal contamination in benthic macroinvertebrates in a sub-basin in the southeast of Brazil. Brazilian Journal of Biology $=$ Revista Brasileira de Biologia, vol. 71, no. 2, pp. 391-399. http://dx.doi. org/10.1590/S1519-69842011000300008. PMid:21755156.

DIGGINS, T.P. and STEWART, K.M., 1993. Deformities of aquatic larval midges (Chironomidae: Diptera) in the sediments of the Buffalo River, New York. Journal of Great Lakes Research, vol. 19, no. 4, pp. 648-659. http://dx.doi.org/10.1016/S03801330(93)71252-6.

DURAI, G. and RAJASIMMAN, M., 2011. Biological treatment of tannery wastewater: a review. Journal of Environmental 
Science and Technology, vol. 4, no. 1, pp. 1-17. http://dx.doi. org/10.3923/jest.2011.1.17.

FANG, G.-C. and YANG, H.C., 2010. Heavy metals in the river sediments of asian countries of Taiwan, China, Japan, India and Vietnan during 1999-2009. Environmental Forensics, vol. 11, no. 3, pp. 201-206. http://dx.doi.org/10.1080/15275922.2010.496709.

HERRICKS, E.E. and CAIRNS JUNIOR, J., 1982. Biological monitorin. Part III: receiving system methodology based on community structure. Water Research, vol. 16, no. 2, pp. 141-153. http://dx.doi.org/10.1016/0043-1354(82)90103-8.

HUDSON, L.A. and CIBOROWSKI, J.J.H., 1996a. Spatial and taxonomic variation in incidence of mouthpart deformities in midge larvae (Diptera: Chironomidae: Chironomini). Canadian Journal of Fisheries and Aquatic Sciences, vol. 53, no. 2, pp. 297-304. http://dx.doi.org/10.1139/f95-199.

INGERSOLL, C.G., 1995. Sediments tests. In: G.M. RAND, org. Fundamentals of aquatic toxicology. Washington: Taylon \& Fancis, pp. 231-241.

JARDIM, G., ARMAS, E. and MONTEIRO, R., 2008. Estudos ecotoxicológicos da água e do sedimento do rio Corumbataí, SP. Brazilian Journal of Biology $=$ Revista Brasileira de Biologia, vol. 68, no. 1, pp. 51-59. http://dx.doi.org/10.1590/S151969842008000100008 .

JORDÃO, C.P., PEREIRA, J.L. and JHAM, G.N., 1997. Chromium contamination in sediment, vegetation and fish caused by tanneries in the State of Minas Gerais, Brazil. The Science of the Total Environment, vol. 207, no. 1, pp. 1-11. http://dx.doi.org/10.1016/ S0048-9697(97)00232-5. PMid:9397595.

JORDÃO, C.P., SILVA, A.C., PEREIRA, J.L. and BRUNE, W., 1999. Contaminação por cromo de águas de rios provenientes de curtumes em Minas Gerais. Quimica Nova, vol. 22, no. 1, pp. 47-52. http://dx.doi.org/10.1590/S0100-40421999000100010.

KHAN, M.A. and GHOURI, A.M., 2011. Environmental pollution: its effects on life and its remedies researcher world. Journal of Arts, Science \& Commerce, vol. 2, no. 2, pp. 276-285.

KUHLMANN, M., HAYASHIDA, C.Y. and ARAUJO, R.P.A., 2000. Using Chironomus sp. (Chironomidade: Diptera) mentum deformities in environmental assessment. Acta Limnologica Brasiliensia, no. 12, pp. 55-61.

LA POINT, T.W., 1995. Signs and measurements of ecotoxicity in the aquatic environment. In: D.J. HOFFMAN, B.A. RATTNER, G.A. BURTAN JUNIOR and J. CAIRRS JUNIOR, eds. Handbook of ecotoxicology. Boca Raton: Lewis Publishers, pp. 13-46.

LAITANO, K.S. and MATIAS, W.G., 2006. Testes de toxicidade com Daphnia magna: uma ferramenta para avaliação de um reator experimental UASB. Journal of the Brazilian Society of Ecotoxicology, vol. 1, no. 1, pp. 43-47. http://dx.doi.org/10.5132/ jbse.2006.01.009.
REJOMON, G., BALACHANDRAN, K.K., NAIR, M., JOSEPH, T., DINESH KUMAR, P.K., ACHUTHANKUTTY, C.T., NAIR, K.K.C. and PILLAI, N.G.K., 2008. Trace metal concentrations in zooplankton from the eastern arabian sea and western bay of Bengal. Environmental Forensics, vol. 9, no. 1, pp. 22-32. http:// dx.doi.org/10.1080/15275920701506193.

REUTHER, R., 1999. Trace metal speciation in aquatic sediments: methods, benefits, and limitations. In: A.M. MURDOCH, J.M. AZCUE and P. MURDOCH, eds. Manual of bioassessment of aquatic sediment quality. Boca Raton: Lewis Publishers, pp. 1-54.

SATTERTHWAITE, D., 1997. Environmental transformations in cities as they get larger, wealthier and better managed. The Geographical Journal, vol. 163, no. 2, pp. 216-224. http://dx.doi. org/10.2307/3060185.

SREENIVASAN, R.S. and KRISHNA MOORTHY, P., 2011. Biochemical stress of chromium in tannery effluents on the fresh water fish Tilapia mossambica (Pisces). International Journal of Biological \& Medical Research, vol. 3, pp. 616-620.

TAGLIARI, K.C., CECCHINI, R., ROCHA, J.A.V. and VARGAS, V.M., 2006. Mutagenicidade do sedimento e estresse oxidativo hepático em peixes sob a influência de curtumes. Journal of the Brazilian Society of Ecotoxicology, vol. 1, no. 1, pp. 57-61. http:// dx.doi.org/10.5132/jbse.2006.01.012.

TWARDOWSKA, I., 2004. Ecotoxicology, environmental safety, and sustainable development: challenges of the third millennium. Ecotoxicology and Environmental Safety, vol. 58, no. 1, pp. 3-6. http://dx.doi.org/10.1016/j.ecoenv.2004.03.008. PMid:15087156.

U.S. ENVIRONMENTAL PROTECTION AGENCY - USEPA, 1994. USEDPA/600/R-94/024: methods for measuring the toxicity and bioaccumulation of sediment associated contaminants with freshwater invertebrates. Washington.

U.S. ENVIRONMENTAL PROTECTION AGENCY - USEPA, 2002a. Short term methods for estimating the acute toxicity of effluents and receiving waters to freshwater and marine organisms. Washington: Office of Water.

U.S. ENVIRONMENTAL PROTECTION AGENCY - USEPA, 2002b. Short term methods for estimating the chronic toxicity of effluents and receiving waters to freshwater organisms. Washington: Office of Water.

UNIVERSIDADE FEDERAL DE LAVRAS - UFLA, 2008. Zoneamento ecológico-econômico do Estado de Minas Gerais: componentes geofisico e biótico. Lavras: Editora UFLA. 161 p.

WALSH, A.R. and O'HALLORAN, J., 1996. Chromium speciation in a tannery effluent - II. Speciation in the effluent and in a receiving estuary. Water Research, vol. 30, no. 10, pp. 2401-2412. http://dx.doi.org/10.1016/0043-1354(96)00174-1.

ZAGATTO, A. and BERTOLETTI, E., 2006. Ecotoxicologia aquática: princípios e aplicações. São Carlos: Rima. 478 p. 